\title{
IT Infrastructures Sourcing Challenges and Practices of Exploration-for- Exploitation in Public Sector Organizations: A Delphi Study
}

\author{
Dragos Vieru ${ }^{1(\bowtie)}$, Simon Bourdeau ${ }^{2}$, Thibaut Coulon ${ }^{3}$, Élodie Boissières ${ }^{4}$ \\ ${ }_{1,4}$ TÉLUQ University, 5800 rue Saint-Denis \\ Montréal, H2S 3L5, QC, CANADA \\ dragos.vieru@teluq.ca \\ elodie.boissieres@teluq.ca \\ ${ }^{2,3}$ Université du Québec à Montréal, 405 rue Sainte-Catherine Est \\ Montréal, H2L 2C4, QC, CANADA \\ bourdeau.simon.2@uqam.ca \\ coulon.thibaut@uqam.ca
}

\begin{abstract}
Managing information technology infrastructures (ITI) in an effective manner represents a major challenge for any organization and even more for public sector organizations (PSOs) that often lack IT resources and are constrained by tight budgets. Despite the importance of these challenges for practitioners, there is a limited number of studies in this field. Applying the organizational ambidexterity (AO) lens to analyze IT managers' practices of ITI in public sector, with a specific emphasis on sourcing practices, the present study seeks to fill this gap. We present the outcomes of a Delphi study that involved 40 ITI experts from three sectors: public, private, and academic. Public sector practices of exploration-for-exploitation sourcing are discussed in this paper.
\end{abstract}

Keywords: Information technology infrastructures, Public sector organizations, Organizational ambidexterity, Sourcing practices, Delphi study.

\section{Introduction}

Since the dawn of the 21st century, public sector organizations (PSOs) have undergone many changes, not only in their governance structures and managerial approaches, but also in the sourcing models of their information technologies infrastructures (ITI). For most practitioners and scholars, an ITI refers to "the composite of hardware, software and connectivity of an organizational system" [66, p.1747] and "provides services to a range of applications and users, and it is usually managed by the IT-group" [60, p.203].

Managing IT infrastructures represents one of the biggest concerns in PSOs due to the growing financial resources invested in IT projects each year [53]. However, compared to private organizations, PSOs face several other challenges such as the transparency and efficiency required in their IT-related sourcing, the lack of expertise in IT, and the fact that they must trade on public markets and follow governmental regulations [15, 41].

While most public ITI is still provided in-house, to overcome the aforementioned challenges, more and more PSOs are choosing external suppliers in order to: 1) develop, purchase, maintain, and upgrade their ITI, both the hardware and software dimensions [14, 42]; and 2) evaluate, adopt, and implement emerging / new technologies [23, 56]. Since ITI are increasingly complex, the management and sourcing of these infrastructures have become a major problem for public sector IT managers [16, 17]. Despite their importance, the activities and practices related to the managing and sourcing of ITI in PSOs have been scarcely studied and documented in both academic and professional literatures [41]. It appears to be a significant lack of knowledge on the challenges faced by PSOs regarding the decisional process for the management and sourcing of their IT infrastructures.

Governments around the world are struggling to provide efficient and effective public services in order to meet the increasing expectations of citizens while dealing with decreased public resources and budgets at the same time [56]. To address this major problem, governments have initiated IT projects to open their data, which in turn can be used to create transparency and involve the public [35]. For instance, the emergence of cloud computing technologies has opened up new possibilities for many governments that want to implement e-government platforms $[32,56]$ that would enable a government to evolve from being an internal driven organization to being open by providing transparency and accountability, and engaging the public [37]. Another example is the blockchain technology and its application, the distributed ledger, that has the capability to deliver a new kind of trust to a wide range of public 
services [23]. Rapid advances in digital information across many government functions such as "big data" [13] and machine learning [4], will provide better measures of public service outputs that will generate insights into how public agencies perform and use resources. Initiatives to assess and eventually implement these technologies reflect the need to transform and explore new ways to accomplish openness, transparency, accountability and engagement.

There are relentless pressures on IT managers in public services to bring up-to-date their ITI in order to increase the quality of their services. Facing tight budgets, the idea of 'more with less' has become a slogan as IT managers seek improve the quality-of-service delivery [27]. This phenomenon is pervasive - an international trend from which there is no escape for public service managers. This global interest has attracted the attention of key world institutions such as the OECD [e.g., 34] on how modern ITI are the drivers of productivity and efficiency of public services. Some of the identified success factors are 1) implementing digital government strategies; 2) fostering an environment conducive to innovation, and 3) understanding better the effect of budgeting and government regulatory practices. New approaches should consider the inherent trade-offs between existing, known technologies and emerging or new technologies [34]. To accomplish all of this, there is a clear need for public sector IT managers to keep up-to-date existing ITI (exploitation) and at the same time, explore opportunities to implement new technologies (exploration) while aligning their sourcing strategies with the various human resources and budgeting restrictions, and procurement regulations.

There is a general consensus that organizations need to both explore and exploit successfully to survive and thrive $[3,5,24]$. Ambidexterity embodies the idea that enduring success of a firm depends on its ability to exploit current capabilities while concurrently exploring new opportunities as it reconfigures its resources to obtain competitive advantage [5]. Exploitation focuses on efficiency, increasing productivity, and extending operational processes, while exploration concentrates on building emerging capabilities and creating workable business options for the future [39]. It has been suggested that organizations need to both explore and exploit successfully to survive and thrive [3, 5, 24]. Organizational ambidexterity (OA) embodies the idea that enduring success of a firm depends on its ability to exploit current capabilities while concurrently exploring new opportunities as it reconfigures its resources to obtain competitive advantage [39,63]. In their seminal article Tushman and O'Reilly (1996) propose the metaphor of a juggler (an ambidextrous person) to suggest that managers who are capable to integrate and reconcile both exploratory and exploitative activities can continuously produce innovations that would incorporate both incremental and radical innovations. Organizational ambidexterity is about doing both by providing the ability to mitigate the tension between exploration and exploitation in pursuit for competitiveness [29, 63].

In this study we use one of the several applications of the organizational ambidexterity construct, in the sense that we adopt Rothaermel and Alexandre's (2009) view of ambidexterity as a firm's "ability to simultaneously balance different activities in a trade-off situation" (p.759). In this vein, March (1991) indicates that the "essence of exploration is experimentation with new alternatives," whereas the "essence of exploitation is the refinement and extension of existing competences" (p.85). In the context of public sector ITI management and sourcing, we conjecture that IT managers must develop the ability to resolve antinomies or to accommodate apparently opposite or conflicting practices. They will need to either engage in exploitation (refine and extend existing technology), in exploration (search for broader knowledge that helps the organization to acquire and implement new technology), or in a mix of both [54]. We infer that a PSO IT manager will probably source the ITI (known or new technology) either internally (insourcing) or externally (outsourcing).

This exploratory study has a two-fold goal:

1) to identify the main challenges PSOS IT managers face when engaging in ITI sourcing practices; and

2) how do IT managers engage in ITI management and sourcing exploration and/or exploitation.

Attempting to achieve this goal, our study draws on the organizational ambidexterity concept. We first engage in a systematic literature review of the ITI sourcing challenges in public sector, then provide a description of our conceptual foundation. We further explain the methodological approach used in our Delphi study that involved 40 ITI experts from three different sectors: private, public and academic. The outcomes of this study, a list of organizational practices identified by these experts, was analyzed by building on Rosenkopf and Nerkar's (2001) matrix that provides relevant criteria when sourcing for ITI. We focus on two dimensions: 1) insourcing vs. outsourcing and 2) known vs. new technology sourcing. A discussion of the results followed by the presentation of the implications for both scholars and practitioners conclude the paper. Conceptually we identified a specific instance of contextual ambidexterity, manifested as exploration to (continuously) improve exploitation and as such, we label it exploration-for-exploitation. Thus, the present study's goal is to provide the illustration of an instantiation of organizational ambidexterity.

It must be noted that data used in this article is part of a larger research project that had a broader scope and sought to shed light on the issues related to the management of technological and application infrastructures in public organizations, as well as the practices deployed to optimize the management of these infrastructures. In our analysis, 
we focus only on the IT sourcing issues and their related practices undertaken by IT managers as two of the several components of the ITI management process in public sector.

\section{Literature Review: ITI Sourcing Challenges in Public Sector}

Following Paré et al.'s (2015) recommendations, we identified three main categories of challenges related to ITI sourcing faced by IT managers in a public sector context: 1) Strategic-related ITI evolution challenges; 2) ITI sourcing business model challenges; and 3) Emerging technologies adoption issues.

\subsection{Strategic-related ITI evolution challenges}

The extant literature shows four organizational strategy-related challenges that PSOs face: 1) challenges related to hardware and software infrastructures (mostly related to tight budgets and cost cuts); 2) challenges related to internal operational processes (differences in department-based procurement strategies and regulations and policies) (9); 3) challenges related to e-government policies and the necessary infrastructures to align to those policies (10); and 4) challenges stemming from the citizens/users' feedback that push public institutions to becoming smart cities or smart governments (33).

These important issues involve significant ITI transformations (22). It has been suggested that in order to effectively address these challenges, IT managers in public institutions need a consistent strategic alignment of their ITI and business goals in order to increase the quality of public services and meet stakeholders' expectations (33).

\subsection{ITI sourcing business model challenges}

During the last decade, the topic of how sourcing of ITI supposed to be done became more and more prevalent since governments saw a rapid evolution of technologies and a sharp rise in service quality expectations from their respective citizens/users. According to Lember et al. (2018), PSOs prefer private sector tailor-made technologies for their core tasks to the insourced tailor-made solutions. The latter come with considerable transaction costs and are often difficult to implement on time. A recent study suggests that PSOs are forced to adopt new models of business because information technologies are nowadays the essence of up-to-date organizations and that their evolution is occurring at an uncontrollable pace [19]. To address this issue PSOs need to look at outsourcing as an important step in their development since this approach will bring in new technologies faster than the insource approach [12]. Indeed, it has been found that IT managers in static PSOs are slower in implementing changes in their technological routines and therefore struggle to deliver minimum services to their citizens [36].

The extant literature suggests that outsourcing partially, or all of public IT services would provide benefits to the public sector. A first benefit has been identified as being a relief in the maintenance of ITI for the organization that in the same time would also allow to cut on IT overhead expenses while allowing internal and external flexibility [6]. Another benefit would be the ability of public sector IT managers to better achieve strategic goals involving the access to essential or rare resources that would otherwise be more difficult or slower to acquire if insourced [21].

\subsection{Emerging technologies adoption challenges}

Recently we have witnessed the emergence of a new kind of economy: the sharing economy [20]. An annual industry report forecasts an exponential growth of the sharing economy from an estimated $15 \$ b n$ in 2014 to an expected $335 \$ b n$ in 2025 [49]. In this context, the emerging technologies can be seen has an important means to achieve new goals identified in the sharing economy. One of the most promising emerging technology, blockchain, has the potential to solve the issue of the necessary changes in how governments maintain administrative control in a digital world [25]. Blockchain technology is an efficient solution to store persistent objects and assets (such as certificates and licenses, etc.) that will enable strong data security and efficient privacy [45]. It makes possible to have contracts that are embedded in digital code and stored in transparent (increases the public trust) databases, where they are sheltered from deletion and altering. In the public sector, some authors consider blockchain as "an institutional technology of governance that competes with other economic institutions of capitalism, namely firms, markets, networks, and even governments" [11, p.16].

While it looks like a panacea, several issues must be addressed by IT managers in order to have this technology implemented and adopted by organizations: first, there is an important cost associated with the acquisition and implementation of the blockchain infrastructure; second, IT managers must ensure that their IT specialists are trained to use the technology; third, there will be a need for developing applications for blockchain [25]. However, the most important challenge PSOs will face when adopting this technology is how governments will address the impact that 
blockchain will have on the governance of the transactions. Whereas conventional systems have a relatively direct control, the distributed nature of blockchain technology entails important changes in responsibilities and new governance approaches [45].

While not an emergent technology per se, cloud computing (CC) is an emerging IT outsourcing model and it is considered amongst the five most influential technologies in the last decade $[28,58,65]$. Analyzing the benefits of CC technology, Sallehudin et al. (2015) found five factors that can impact its adoption by the PSOs: 1) the potential lack of compatibility (similar objectives with the organizations' work behavior, values, experience and practice); 2 ) the complexity (perception of the technology as being complex and difficult to use); 3 ) the potential lack of ability to try, test, or experiment; 4) IT personnel characteristics (lack of knowledge of the technology and power of persuasion); 5) lack of openness to new technology. Information security and privacy were also identified as significant challenges to adopt cloud computing [18].

In sum, the extant literature on ITI sourcing in public sector suggests that IT managers in PSOs need to adapt to a faster and constant technological evolution driven by: 1) performance / capacity enhancements, new functionalities, and frequent new software releases [40]; 2) opportunities to outsource some of their IT infrastructures installation and maintenance [12]; 3) growing importance given to citizens/users' feedback about their needs [36]; 4) unavoidable changes in the traditional organizational governance models [45].

\section{Organizational Ambidexterity}

The concept of organizational ambidexterity (OA) represents a firm's ability to simultaneously explore and exploit, enabling a firm to succeed at adaption over time rather than pursuing one of the two activities exclusively [29, 44].

Structural ambidexterity. The concept of structural ambidexterity advances the idea that organizational structures should divide exploitative and explorative practices into separate organizational units, each with distinct competencies, processes, and cultures, while at the same time implementing a process of integration between exploration and exploitation [29, 63]. In other words, this implies that successful ambidexterity is conditioned by the capability of an organization to have different business units able to focus on operation activities, while others focus on adaptation [5].

Contextual ambidexterity. Unlike structural ambidexterity, contextual ambidexterity is an approach that enables organizations to balance exploitative and explorative tasks without separating them [2, 29]. In this perspective, ambidextrous organizations enable an organizational context that foster and encourages the flexibility of employees to use their own judgment in how and when they will efficiently divide their time between the conflicting demands of exploitation and exploration across the same business unit [5, 24]. In this way, contextual ambidexterity enables firms to avoid going in a direction of change without regard to its bottom line [39]. The contextual approach supports O'Reilly and Tushman's (2013) argument that a firm that is capable of exploring and exploiting simultaneously is likely to realize superior performance compared to firms that favor one over the other. A successful implementation of this philosophy is Toyota. Adler et al.'s (1999) case study examines the contextual factors that contribute to ambidexterity between firm flexibility and efficiency. The authors found that reconciling the contextual factors of support, training and trust, increased the organization's capacity for flexibility at a given level of efficiency, and created capabilities that served to improve efficiency [1].

The literature on OA suggests the path from ambidexterity to organizational performance presents implementation challenges, particularly related to the need to and achieve flexibility in the allocation of company resources across alignment and adaptability activities [44, 63]. While some ambidexterity researchers assume that in general resources are available and that managers across the organization have equal access to them [44, 59], others suggest that this assumption is not always valid [31]. The amount of human capital required favors larger businesses' efforts to create and sustain ambidexterity. Ambidextrous organizations invest heavily in their pool of human resources so that employees are well-trained, skilled, motivated, and empowered to efficiently balance exploitation and exploration practices $[38,50]$. Most theories regarding ambidexterity assume that organizations are large enough to allocate sufficient resources managers to fostering and maintaining an ambidextrous environment $[24,38]$. However, in our context, the ideal route for an IT manager in a public sector organization with fewer resources and constrained by tight budgets and governmental regulations to pursue ITI sourcing ambidexterity requires more analysis.

\section{Research Design: Delphi Method}

Our literature review shows that PSOs face important challenges. However, the literature is relatively limited regarding how these challenges are overcome by ITI managers. Thus, to better understand how ITI manages overcome these challenges, and more specifically, to better understand the sourcing practices deployed, a Delphi study was conducted 
$[43,47]$. The objectives are, first to identify the management and sourcing practices deployed by IT managers to overcome the challenges and second, to have a better understanding how IT managers balance their sourcing practices, in terms of exploitation and exploration, in order to generate ambidexterity.

The Delphi method allows a panel of experts to communicate and exchange, in an interactive and structured way, to identify, select and classify different ideas such as problems, key success factors or good practices [47, 55]. We chose the Delphi method because it has been used successfully in complex areas requiring expert conclusions [e.g., 55]. We followed the suggested steps to conduct a Delphi study [57] as well as the recommendations formulated by experts [47] in the elaboration of the methodological design.

In the present study, out of the 62 IT infrastructure management experts that were contacted, 40 accepted to participate in the study. In order to have a complementary perspective IT infrastructure, managers from private organizations as well as IT researchers from the academia were invited to participate in the study. During the Delphi study, experts had to identify and classify practices deployed to manage their ITI in terms of: 1) exploitation, e.g., practices deployed to extend the sustainability of their existing IT infrastructure and 2) exploration, e.g., the practices deployed to seize the opportunities related to the constant and rapid technological evolution. To do so, data collection process followed the three main phases underlying the Delphi method: 1) brainstorming; 2) narrowing; and 3) ranking [47].

\subsection{Experts Selection}

Choosing the right experts is one of the most, if not the most important step in the Delphi process. Indeed, an important relation exists between the selection and the quality of the results generated [47]. We followed Okoli and Pawlowski's (2004) and Paré et al.'s (2013) recommendations on experts selection. The experts selected had to have: 1) knowledge and expertise related to the management of ITIs in private or public organizations and/or 2) conducted studies (e.g. scholars) in the field of IT. Recruitment of the ITI experts was based on the authors' professional networks. The 40 experts that agreed to participate in the Delphi study were divided into three groups of experts: public, private and academic sectors. Table 1 illustrates the main demographic data of the expert panel. Due to the extended length (4 months) of the Delphi process, 6 experts had quit the study at different moments along the 3 phases: 4 practitioners, 1 academic, and 1 from public sector. Thus, at the end of the last phase (ranking), the panel had 34 experts.

\begin{tabular}{|l|c|c|c|c|}
\hline \multirow{2}{*}{} & \multicolumn{4}{|c|}{ Sectors } \\
\cline { 2 - 5 } & Public & Private & Academic & Total \\
\hline Number of respondents & $14(13)$ & $15(11)$ & $11(10)$ & $40(34)$ \\
\hline Age (avg.) & 48 & 48 & 46.3 & 47.1 \\
\hline Professional experience (years) & 25.3 & 23.3 & 20.2 & 23.15 \\
\hline IT Professional experience (years) & 19 & 18.2 & 15 & 17.6 \\
\hline
\end{tabular}

Table 1. Demographics in the Delphi Study

\subsection{Step \#1: Brainstorming and Validation}

The questionnaires sent to the experts in the first step, brainstorming, was divided in three sections: 1) demographic; 2) a question on the exploitation practices related to the management of ITI and 3) a question on the exploration practices related to the management of ITI. Our two questions focused on the ITI managerial practices in general rather than only on the sourcing practices. By asking the experts to focus on managerial practices in general rather than only on sourcing one, the objective was to ensure that they would take a general perspective on the practices deployed to overcome the challenges of managing ITI. By asking the experts to focus only on one underlying dimension of ITI management, e.g., the sourcing practices, we would have had a partial perspective. Thus, we conducted a Delphi study that focused on the managerial practices to exploit and explore ITI. However, in this paper, our analysis focused on the practices related to ITI sourcing. Thus, the questions on exploitation and exploration practices were:

Exploitation-focus question: What are the practices/strategies that can be used by organizations in general to extend the sustainability of their existing IT infrastructure, e.g., those currently deployed? These practices / strategies can be technical, strategic, organizational, human, etc.

Exploration-focus question: What are the practices/strategies used by organizations to overcome the challenges and seize the opportunities related to the constant and rapid technological evolution? 
Each expert was asked to provide a minimum of 6 answers (practices) per question. For each response, the experts had to provide a label describing the identified practice as well as a short description. The questionnaire was pre-tested with three IT experts (non-participants) to assess the clarity of the question, the design of the questionnaire and the approximate time required to complete it.

The experts identified 180 different practices for the exploitation-focused question and 198 different practices for the exploration-focused question. Data were compiled using MS Excel. The experts' answers and explanations were analyzed first individually, and then collectively by the first three authors. The purpose of this analysis was to group and synthesize all of these responses. Analogous and overlapping responses were grouped under the same label and, for each of these labels, a description was written based on the descriptions provided by the experts. A total of 45 labels were identified for the exploitation-focused question. To facilitate the interpretation, those labels were grouped into 5 categories: 1) knowledge management and competencies, 2) governance, 3) partnership, 4) strategic, and 5) technology. A total of 42 labels were identified for the exploration-focused question. To facilitate the interpretation, those labels were grouped into 6 categories: 1) employees, 2) technology, 3) architecture, 4) strategy, 5) collaboration, and 6) monitoring. Afterwards, a validation round was conducted to confirm the consolidated list of the identified practices in terms of meaning and representativeness. Thus, the experts were given the possibility to add, if needed, practices that they might have missed or forgot during the first round as well as to validate all the labels and definitions. The final lists are presented in Appendix 1 (for the exploitation-focused practices) and in Appendix 2 (for the exploration-focused practices).

\subsection{Step \#2. Narrowing and Step \#3. Ranking}

In the second step, narrowing, the experts were provided with the two lists and were asked to select, in each of them, the 10 most important practices, based on their respective effectiveness, without ranking them. For this steps and the following ones, the practices identified as important by each experts' group, private, public, and academic, were treated separately. For the questionnaires received, a selection rule was established following the recommendations of Delphi experts [43, 47], and applied to narrow the list of the most important practices. Thus, to be selected and incorporated in the lists used in the ranking step, a specific practice had to be identified by at least by $40 \%$ of the experts.

In the third and last step, ranking, the participants received two lists: one of the most important exploitationfocused practices and another of the exploration-focused practices as identified by the experts in step 2. In that last steps, the experts were asked to rank them in order of the level of their effectiveness ( 1 to $\mathrm{N}$, where $1=$ the most important/effective and $\mathrm{N}$ was the least important/effective). Appendix 3 (exploitation-focused practices) and Appendix 4 (exploration-focused practices) present the final rankings.

\subsection{Consensus creation}

Afterwards, the ranking of each practices, as well as the Kendall W coefficient, were calculated [30]. The Kendall $\mathrm{W}$ coefficient was used to establish the level of consensus between the participating experts. It should be noted that a Kendall coefficient of $\mathrm{W}=1.0$ would mean that all the participating experts would perfectly agree with one another regarding the ranking of the practices [18]. It has been suggested that a consensus level $\mathrm{W}<0.3$ is considered low, between 0.3 and 0.5 , it is considered moderate, between 0.5 and 0.7 it is considered good, and greater than 0.7 is considered strong [8]. Since all consensus coefficients (W) were less than 0.3 in the first round, a second ranking round was conducted. In the second round, the experts received a list presenting the organizational practices to be ranked accompanied by the average results obtained during the first ranking round. As it can be observed in Table 2, the consensus levels between the first and second rounds improved significantly.

\begin{tabular}{|l|c|c|}
\hline \multicolumn{1}{|c|}{ Panels } & \multicolumn{2}{c|}{ Kendall's $\boldsymbol{W}$} \\
\hline Experts from the academic sector & Round \#1 & Round \#2 \\
\hline Experts from the public sector & 0.06 & 0.44 \\
\hline Experts from the private sector & 0.13 & 0.54 \\
\hline
\end{tabular}

Table 2. Kendall W coefficient level 


\section{Coding and Results}

The first step taken to analyze the Delphi data was to identify and extract all the practices related to sourcing from the two complete lists, the exploitation-focused and the exploration-focused practices. We also defined what sourcing will entail for us. In general sourcing represents the process of choosing or procuring IT resources, e.g., materials, software and services from an external or internal service provider. Sourcing may also focus on practices that could play a strategic role such as supplier management, contract development, supplier selection, contract negotiation, etc. Sourcing could also be related to the practice of identifying and recruiting talent for specific processes and/or functions. It has been found that "technology-sourcing decisions" are central to any organization and focuses on an organization's "decisions to broaden their technological portfolios through licensing agreements, a form of market contract, or acquisition" [61, p.272].

Thus, organizations acquire technological know-how by either: (1) developing their technology independently, (2) acquiring other organizations which possess the desired ITI, or (3) entering into a technology sourcing agreement. Oshri et al. (2015) provide a more clear and encompassing definition of sourcing: "Sourcing is the act through which work is contracted or delegated to an external or internal entity that could be physically located anywhere. IT encompasses various insourcing (keeping work in-house) and outsourcing arrangements such as offshore outsourcing, captive offshoring, nearshoring and onshoring" (p.7). We used this definition to assess and classify the complete list of exploitation and exploration practices identified in the Delphi study.

First, each of the practices listed in Appendices 1 and 2 were classified as sourcing-related or not. Second, we tried to characterize each of the sourcing-related practices according to the two dimensions adapted from Rosenkopf and Nerkar's (2001) framework: 1) ITI sourcing approach (insourcing vs. outsourcing), and 2) type of sourced technology (known vs. new technology). This classification was done in two steps. First, the practices listed in Appendices 1 and 2 were separately classified by two of the authors using Oshri et al.'s (2015) sourcing definition. The practices were grouped by categories ( 5 categories for the exploitation and 6 categories for the exploration practices).

The second step was to compare the two classifications and discuss the differences between the two classifications. The outcome was that about $10 \%$ of the identified practices were not classified the same way by the first two authors. In order to resolve the differences and reach consensus, the authors met to discuss gaps and yield a common classification. Because the classification was based on the interpretations of each practice description and that these descriptions were not always clear regarding the underlying ITI sourcing approach and/or the type of sourced technology (new vs. known), some of the sourcing practices have been classified into more than on class. Tables 3 and 4 present the sourcing practices identified during the narrowing and ranking phases and categorized by sector (public, private, and academic), while Table 5 presents the practices that can be described as instances of ambidexterity manifested as exploration to (continuously) improve exploitation (exploration-for-exploitation).

\begin{tabular}{|c|c|c|c|c|}
\hline \multirow{2}{*}{$\begin{array}{c}\# \\
\text { (App.1 } \\
\text { ) }\end{array}$} & \multirow[b]{2}{*}{ EXPLOITATION-Focused Sourcing Practices } & \multicolumn{3}{|c|}{ Ranking } \\
\hline & & Public & Private & Academic \\
\hline 33. & Acquire reliable technological equipment & 2 & & \\
\hline 44. & Virtualize servers & 3 & 7 & \\
\hline 42. & Ensure redundancy of critical components & 5 & & \\
\hline 43. & Virtualize infrastructure & 6 & 6 & \\
\hline 37. & Implement a Service Oriented Architecture & 7 & 5 & \\
\hline 28. & Develop and monitor maintenance and replacement plans & 10 & & \\
\hline 7. & Transfer and duplicate IT Skills & 13 & 11 & \\
\hline 26. & Develop a strategic vision of technological infrastructure & & 1 & 1 \\
\hline 45. & Virtualize storage & & 3 & 10 \\
\hline 27. & $\begin{array}{r}\text { Develop and document the business architecture plan } \\
\text { (including technology infrastructure) }\end{array}$ & 14 & 4 & \\
\hline 5. & Establish a continuous improvement program & 4 & 12 & 3 \\
\hline 9. & Adopt a modular approach & & & 6 \\
\hline
\end{tabular}

Table 3. Exploitation-focused sourcing practices ranked by the experts 


\begin{tabular}{|c|c|c|c|c|}
\hline \multirow{2}{*}{$\begin{array}{c}\# \\
\text { (App.2 } \\
\text { ) }\end{array}$} & \multirow[b]{2}{*}{ EXPLORATION-Focused Sourcing Practices } & \multicolumn{3}{|c|}{ Ranking } \\
\hline & & Public & Private & Academic \\
\hline 9. & Adopting reliable and evolutive technologies & 1 & & \\
\hline 35. & Develop collaboration between IT and business units & 2 & 3 & 1 \\
\hline 30. & Implement mechanisms for continuous improvement & 4 & 9 & 5 \\
\hline 20. & Define a corporate architecture framework & 5 & & \\
\hline 29. & Assess internal and external technological risks & 10 & & \\
\hline 16. & Reuse of IT assets & 13 & & 9 \\
\hline 31. & Outsource & 14 & & 15 \\
\hline 21. & Define life cycle and design a roadmap & & 4 & \\
\hline 42. & Use of external experts & & 8 & \\
\hline 12. & Migrate to cloud computing & 3 & 10 & 11 \\
\hline 15. & Use of business and artificial intelligence & & 12 & 12 \\
\hline 33. & $\begin{array}{r}\text { Develop collaboration between development and operation } \\
\text { teams }\end{array}$ & & & 3 \\
\hline 34. & Develop collaboration between IT and external partners & & & 8 \\
\hline
\end{tabular}

Table 4. Exploration-focused sourcing practices ranked by the experts

\begin{tabular}{|c|c|c|c|c|}
\hline $\begin{array}{c}\# \\
\text { (App.1) }\end{array}$ & $\begin{array}{c}\text { EXPLOITATION - Focused } \\
\text { Practices }\end{array}$ & & EXPLORATION - Focused Practices & $\begin{array}{c}\# \\
\text { (App.2) }\end{array}$ \\
\hline 5. & $\begin{array}{r}\text { Establish a continuous improvement } \\
\text { program }\end{array}$ & $\leftrightarrow$ & $\begin{array}{l}\text { Implement mechanisms for continuous } \\
\text { improvement }\end{array}$ & 30. \\
\hline 9. & Adopt a modular approach & $\leftarrow$ & $\begin{array}{l}\text { Adopt an architecture in micro-services and } \\
\text { modules }\end{array}$ & 18. \\
\hline 16. & $\begin{array}{l}\text { Establish and monitor the evolution of } \\
\text { the portfolio of the components of the } \\
\text { technological infrastructure }\end{array}$ & $\leftrightarrow$ & Adopt a portfolio management approach & 25. \\
\hline \multirow[t]{2}{*}{19.} & \multirow{2}{*}{$\begin{array}{r}\text { Establish inter-organizational } \\
\text { partnerships }\end{array}$} & $\leftarrow$ & $\begin{array}{l}\text { Develop collaboration between IT and external } \\
\text { partners }\end{array}$ & 34. \\
\hline & & $\leftrightarrow$ & Develop partnership & 36. \\
\hline 22. & $\begin{array}{r}\text { Use of external consultants specialized in } \\
\text { the management of the technological } \\
\text { infrastructure }\end{array}$ & $\leftrightarrow$ & Use of external experts & 42. \\
\hline 23. & $\begin{array}{r}\text { Use of external services (e.g. } \\
\text { outsourcing) }\end{array}$ & $\leftarrow$ & Outsource & 31. \\
\hline 25. & $\begin{array}{r}\text { Develop an organizational policy on } \\
\text { "Bring your own devices (BYOD)" }\end{array}$ & $\leftarrow$ & $\begin{array}{l}\text { Adopt a "bring your own devices" approach } \\
\text { (BYOD) }\end{array}$ & 24. \\
\hline 27. & $\begin{array}{r}\text { Develop and document the business } \\
\text { architecture plan (including technology } \\
\text { infrastructure) }\end{array}$ & $\leftrightarrow$ & Define a corporate architecture framework & 20. \\
\hline 28. & $\begin{array}{r}\text { Develop and monitor maintenance and } \\
\text { replacement plans }\end{array}$ & $\leftrightarrow$ & Define life cycle and design a roadmap & 21. \\
\hline 31. & Establish a service offer & $\leftarrow$ & Expand the IT service offering & 28. \\
\hline 33. & Acquire reliable technological equipment & $\leftrightarrow$ & Adopting reliable and evolutive technologies & 9. \\
\hline 37. & $\begin{array}{r}\text { Implement a Service Oriented } \\
\text { Architecture }\end{array}$ & $\leftrightarrow$ & Adopt a service-oriented architecture (SOA) & 19. \\
\hline 43. & Virtualize infrastructure & $\leftrightarrow$ & Migrate to cloud computing & 12. \\
\hline 44. & Virtualize servers & $\leftarrow$ & Migrate to cloud computing & 12. \\
\hline 45. & Virtualize storage & $\leftarrow$ & Migrate to cloud computing & 12. \\
\hline
\end{tabular}

Table 5. Exploration-for-exploitation sourcing practices based on ranking 
To identify the ambidexterity instances, for each of the exploitation-focused sourcing practice identified, we provided its 'twin' in the list of exploration-focused practices (Table 5). In order to perform the 'matching', we read and interpret each practice description identified at the end of the ranking phase (Appendices 3 and 4).

The identification numbers (\#) presented in the first column are those ones identified in Appendix 1 (for Table 3) and Appendix 2 (for Table 4). Since no matching was perfect, the exploitation-exploration pairs of practices presented in Table 5 were matched only when a significant overlap was present. Six (6) public sector exploration-for-exploitation sourcing practices were identified (pairs \#5/30, 27/20, 28/21, 33/9, 43/12, 44/12).

\section{Discussion}

We conducted a Delphi study with 34 experts from three sectors: public, private, and academic, to identify various ITI sourcing practices. In order to analyze these practices, we adapted Rosenkopf and Nerkar's (2001) framework that provides important criteria when sourcing for IT and focuses on two dimensions: 1) ITI sourcing approach (insourcing vs. outsourcing); and 2) Type of sourced technology (known vs. new technology).

Focusing on sourcing exploitation practices, more than half of the practices suggested by the experts (14 out of 24) were related to both internally and externally sourcing approaches (insourced and outsourced), which indicates a certain flexibility in their application (see Appendix 1). Several practices (7 out of 24) involved a purely outsourcing approach, which shows an important interest towards this type of sourcing approach. For instance, practices such as establishing inter-organizational partnerships, or renegotiating contracts for extension have been suggested. In addition, although a majority of exploitation practices oriented towards sourcing known technologies were expected, the results show that the practices put in place target both the sourcing of known technologies and also new ones.

Similarly, several sourcing exploration practices ( 9 of 22) were related to both internally and externally sourcing approaches (insourced and outsourced). In total, 17 of the 22 exploration practices have an outsourcing approach, while 14 have an insourcing approach (see Appendix 2). On the other hand, exploration practices were, for the most part, oriented towards new technologies (20 out of 22) compared to known technologies (8 out of 22).

Further, out of the 46 sourcing practices (24 in exploitation - see Appendix 3; 22 in exploration - see Appendix 4), 15 (5 in the public sector), were identified as exploration-for-exploitation (instances of contextual ambidexterity) which represents an interesting and important preliminary result. These 5 practices not only allow PSOs to exploit their ITI but also explore new opportunities. For example, adopting reliable and scalable technologies is the most important practice, according to the PO experts' ranking, and this practice not only allows PSOs to better exploit their ITI, but also enable them to cope with the rapid evolution of technologies. Among the other important ambidextrous practices, we found server virtualization, classified as a major exploitation practice but also having an impact on exploration, the implementation of continuous improvement mechanisms (rank 4 of exploration practices and also having an impact on exploitation), or the definition of an architectural framework (rank 14 of exploration practices and allowing organizations to keep up-to-date their existing ITI). The identification of these 5 contextual ambidextrous practices is an important starting point for PSOs wishing to efficiently allocate resources while being limited by tight budgets.

When comparing the exploitation ITI sourcing practices (see Table 5, left column) with the exploration ITI sourcing practices (see Table 5, right column), we observe that these practices are very similar in the way they were labeled by the experts. An obvious question raises: Is this a methodological error that has generated these results or rather those pairs are complementary? There is a possibility that these outcomes are caused by the fact that the same respondents identified both the exploitation and the exploration ITI sourcing practices. However, to minimize this possible error, two distinct questions, focusing on ITI management in general and not only on sourcing practices, where asked: one related to practices to extend the sustainability of their existing IT infrastructure (exploitation), and the other one related to practices to overcome challenges and exploit the opportunities related to the constant and rapid technological evolution (exploration).

Thus, we suggest that we identified several prominent practices of cross-over, i.e. complementary practices that we label them exploration-for-exploitation practices. Overall, a complex relational pattern and virtuous cycle has emerged. We conjecture that exploitation and exploration ITI sourcing practices feed or influence each other in the sense that the decisions made in terms of exploitation ITI (known or new) sourcing will constraint or orientate the avenues to explore in terms of exploration ITI (known or new) sourcing practices [51]. The exploitation decisions put an organization, especially a PSO that has tight budgets and human resources, on a certain path and thus the exploration ITI sourcing practices are path depend of the exploitation decisions [62]. Furthermore, the decision to engage in specific exploration ITI sourcing practices will feed or influence exploitation ITI sourcing practices in the sense that 
these decisions will generate new possibilities, new avenues in terms of sourcing practices which may not have been considered when engaged in previous exploitation ITI sourcing practices.

Thus, we suggest that exploitation and exploration ITI sourcing practices are interrelated and could be illustrated in terms of a continuous lifecycle [26,64]. When deploying exploitation sourcing practices, managers should think about the durability of the ITI but simultaneously be mindful of how the ITI could or will evolve in the future since exploration practices will have an important impact on exploitation practices.

\section{Conclusion}

With the rapid and constant technological evolution, public sector organizations face important challenges regarding the decisional process of sourcing their IT infrastructures. Because of the extant academic and practitioner literatures' lack of pertinent studies on this important topic, this study is a first step to fill this gap by conducting a systematic review of the literature and a Delphi study. We have empirically identified ambidextrous ITI sourcing practices and proposed a contextualized view on challenges and related responses in three different sectors (public, private, and academic), with a specific focus on the public sector in this article.

Our main theoretical contribution is thus a sector specific instantiation of ambidexterity, which highlights specifically the benefits of exploration-for-exploitation practices. Our findings - as expected - are highly contextualized and contingent on the organizations (PSOs). From a practitioner's point of view, the study should help IT managers better react when confronted with new emerging technologies. It should also be beneficial for practitioners to learn how their colleagues from other sectors, especially the ones from the private sector, adopt and implement various organizational actions to face technological evolution and better source and manage their ITI. The results should also help public sector officials to identify cross-sectoral differences with private sector organizations and help them eventually better collaborate with private sector partners. Facing tight budgets and relentless pressures from the public, IT managers in public institutions must bring up to date their infrastructures in order to increase the quality of their services. The experts in our study suggested that reliable technological infrastructures are the raison d'être of their PSOs trying to keep in touch with the present reality of the digital world.

The closer you look, the more the distinction between quality delivery on one hand, and continuous improvement, creativity, and innovation on the other hand, becomes blurred (cross-over between exploration and exploitation). We have identified and evidenced an instance of contextual ambidexterity: exploration-for-exploitation, in other words, continuous improvement of the IT infrastructures that has become honed as integral part of the ambidextrous practices of the IT managers involved in our Delphi study.

Some limitations of the present study need to be acknowledged. First, even if the organizational actions were identified by 40 ITI experts and that a rigorous Delphi study was used, caution must be exercised before generalizing the results and systematically apply them in any organizational context. Second, the cross-sectional nature of the data collection limits the ability to explore how organizational actions might have interacted with one another throughout time.

We hope that the results of this study will guide and assist practitioners in their decision making as well as researchers in their investigation of issues related to the management of technological infrastructures. In this sense, we propose several avenues for future research. First, it would be noteworthy to assess the impact of sourcing practices identified in this study on organizational performance. Another research avenue would be to evaluate to what extent each of the identified sourcing practices would be easy or not to implement. Finally, it would also be interesting to analyze to what extent the proposed sourcing practices would increase the capacity and flexibility of the IT infrastructures $[7,66]$.

\section{Acknowledgments}

This research project was funded by and realized with the collaboration of the Center for Interuniversity Research and Analysis of Organizations - CIRANO (https://cirano.qc.ca/en). 


\section{References}

1. Adler, P. S., Goldoftas, B., and Levine, D. I. (1999). Flexibility versus efficiency? A case study of model changeovers in the Toyota production system, Organization Science, 10(1), pp.43-68.

2. Andriopoulos, C., and Lewis, M.W. (2009). Exploitation-exploration tensions and organizational ambidexterity: managing paradoxes of innovation, Organization Science, 20(4), pp.696-717.

3. Alves, M., Galina, S., and Dobelin, S. (2018). Literature on organizational innovation: past and future, Innovation \& Management Review, 15(1), pp. 2-19.

4. Armstrong, H. (2015). Machines that learn in the wild: Machine learning capabilities, limitations and implications. NESTA, London, https://media.nesta.org.uk/documents/machines_that_learn_in_the_wild.pdf (accessed on 07/01/2020).

5. Birkinshaw, J., and Gibson, C. B. (2004). Building an ambidextrous organization, MIT Sloan Management Review, pp.47-55.

6. Burnes, B., and Anastasiadis, A. (2003). Outsourcing: a public-private sector comparison. Supply Chain Management: An International Journal, 8(4), pp.355-366.

7. Bush, A. A., Tiwana, A., and Rai, A. (2010). Complementarities between product design modularity and IT infrastructure flexibility in IT-enabled supply chains. IEEE Transactions on Engineering Management, 57(2), pp.240-254.

8. Cafiso, S., Di Graziano, A., and Pappalardo, G. (2013). Using the Delphi Method to Evaluate Opinions of Public Transport Managers on Bus Safety. Safety Science, (57), pp.254-263.

9. Campbell, J., McDonald, C., and Sethibe, T. (2010). Public and private sector IT governance: Identifying contextual differences. Australasian Journal of Information Systems, 16(2), pp.5-18.

10. Cordella, A., \& Iannacci, F. (2010). Information systems in the public sector: The e-Government enactment framework. The Journal of Strategic Information Systems, 19(1), pp.52-66.

11. Davidson, S., De Filippi, P., and Potts, J. (2016). Disrupting governance: The new institutional economics of distributed ledger technology, available at SSRN 2811995.

12. Duhamel, F., Gutierrez-Martinez, I., Picazo-Vela, S., and Luna-Reyes, L. (2014). IT outsourcing in the public sector: a conceptual model. Transforming Government: People, Process and Policy, 8(1), pp.8-27.

13. Dunleavy, P. (2017). Public sector productivity. OECD Journal on Budgeting, 17(1), pp.1-28.

14. Edberg, D., Ivanova, P., and Kuechler, W. (2012). Methodology mashups: An exploration of processes used to maintain software. Journal of Management Information Systems, 28(4), pp.271-304.

15. Edler, J., and Georghiou, L. (2007). Public procurement and innovation - Resurrecting the demand side. Research Policy, 36(7), pp.949-963.

16. Edler, J., and Yeow, J. (2016). Connecting demand and supply: The role of intermediation in public procurement of innovation. Research Policy, 45(2), 414-426.

17. Edquist, C., and Hommen, L. (2000). Public technology procurement and innovation theory. In: Public technology procurement and innovation, pp. 5-70, Springer, Boston, MA.

18. El-Gazzar, R., Hustad, E., and Olsen, D. H. (2016). Understanding Cloud Computing Adoption Issues: A Delphi Study Approach, Journal of Systems and Software, 118, pp. 64-84.

19. Ferreira, M. J., Moreira, F., \& Seruca, I. (2019). Enterprise 4.0: The next evolution of business?, In: New Perspectives on Information Systems Modeling and Design, pp. 98-121, IGI Global.

20. Ganapati, S., and Reddick, C. G. (2018). Prospects and challenges of sharing economy for the public sector. Government Information Quarterly, 35(1), pp.77-87.

21. Gantman, S. (2011). IT outsourcing in the public sector: A Literature Analysis. Journal of Global Information Technology Management, 14(2), pp.48-83.

22. Gil-Garcia, J. R., Helbig, N., and Ojo, A. (2014). Being smart: Emerging technologies and innovation in the public sector. Government Information Quarterly, 31, pp.I1-I8.

23. Government Office for Science (2016), Distributed Ledger Technology: beyond block chain: A report by the UK Government Chief Scientific Adviser, Government Office for Science, London, www.gov.uk/government/uploads/system/uploads/attachment_data/file/492972/gs-16-1-distributed-ledgertechnology.pdf (accessed on 07/01/2020).

24. Gibson, C. B., and Birkinshaw, J. (2004). The antecedents, consequences, and mediating role of organizational ambidexterity. Academy of Management Journal, 47(2), pp.209-226.

25. Iansiti, M., and Lakhani, K. R. (2017). The truth about blockchain, Harvard Business Review, 95(1), pp.118-27.

26. Howard-Grenville, J. A., and Rerup, C. (2017). Handbook of Process Organizational Studies, Sage, Thousand Oaks. 
27. Ho, A. T. K. (2018). From performance budgeting to performance budget management: theory and practice. Public Administration Review, 78(5), pp.748-758.

28. Kappelman, L., McLean, E., Luftman, J., and Johnson, V. (2013). Key Issues of IT Organizations and Their Leadership: The 2013 SIM IT Trends Study. MIS Quarterly Executive, 12(4), pp.227-240.

29. Kauppila, O.-P. (2010). Creating Ambidexterity by Integrating and Balancing Structurally Separate Interorganizational Partnerships. Strategic Organization, 8(4), pp.283-312.

30. Kendall, M., and Gibbons, J. (1990). Rank Correlation Methods (Charles Griffin Book Series), Oxford University Press.

31. Kyriakopoulos, K., and Moorman, C. (2004). Tradeoffs in marketing exploitation and exploration strategies: The overlooked role of market orientation. International Journal of Research in Marketing, 21(3), pp.219-240.

32. Kuiper, E., Van Dam, F., Reiter, A., and Janssen, M. (2014). Factors influencing the adoption of and business case for Cloud computing in the public sector. eChallenges e-2014 Conference Proceedings, IEEE, pp.1-10.

33. Laita, A. and Belaissaoui, M. (2017). Information Technology Governance in Public Sector Organizations. In: Europe and MENA Cooperation Advances in Information and Communication Technologies, pp.331-340, Springer.

34. Lau, E., Lonti, Z., and Schultz, R. (2017). Challenges in the measurement of public sector productivity in OECD countries. International Productivity Monitor, 32, pp.180-195.

35. Lee, G., and Kwak, Y. H. (2012). An open government maturity model for social media-based public engagement. Government Information Quarterly, 29(4), pp.492-503.

36. Lember, V., Kattel, R., and Tonurist, P. (2018). Technological capacity in the public sector: the case of Estonia. International Review of Administrative Sciences, 84(2), pp.214-230.

37. Lourenço, R. P. (2015). An analysis of open government portals: A perspective of transparency for accountability. Government Information Quarterly, 32(3), pp.323-332.

38. Lubatkin, M. H., Simsek, Z., Ling, Y., and Veiga, J. F. (2006). Ambidexterity and performance in small-to medium-sized firms: The pivotal role of top management team behavioral integration, Journal of Management, 32(5), pp.646-672.

39. March, J. G. (1991). Exploration and Exploitation in Organizational Learning. Organization Science, 2(1), pp.7187.

40. Moe, C.E., and Päivärinta, T. (2013). Challenges in Information Systems Procurement in the Public Sector. Electronic Journal of e-Government, 11(1), pp.307-322.

41. Moe, C.E., (2014). Research on Public Procurement of Information Systems: The Need for a Process Approach. Communications of the Association for Information Systems, 34, Article 78, pp.1391-1335.

42. Moe, C.E., Newman, M., and Kyaw Sein, M. (2017). The public procurement of information systems: dialectics in requirements specification. European Journal of Information Systems, 26(2), pp.143-163.

43. Okoli, C., and Pawlowski, S. D. (2004). The Delphi method as a research tool: an example, design considerations and applications. Information \& Management, 42(1), pp.15-29.

44. O'Reilly, C. A., and M. L. Tushman. (2013). Organizational Ambidexterity: Past, Present, and Future. Academy of Management Perspectives, (27:4), pp.324-338.

45. Ølnes, S., Ubacht, J., and Janssen, M. (2017). Blockchain in government: Benefits and implications of distributed ledger technology for information sharing. Government Information Quarterly, (34), pp.355-364.

46. Oshri, I., Kotlarsky, J., and Willcocks, L. P. (2015). The Handbook of Global Outsourcing and Offshoring, 3rd Edition. New York, NY: Palgrave Macmillan.

47. Paré, G., Cameron, A.-F., Poba-Nzaou, P., and Templier, M. (2013). A systematic assessment of rigor in information systems ranking-type Delphi studies. Information \& Management, 50(5), pp.207-220.

48. Paré, G., Trudel, M. C., Jaana, M., and Kitsiou, S. (2015). Synthesizing information systems knowledge: A typology of literature reviews. Information \& Management, 52(2), pp.183-199.

49. PricewaterhouseCoopers (2015). The sharing economy: Consumer intelligence series, https://www.pwc.com/us/en/technology/publications/assets/pwc-consumer-intelligence-series-the-sharingeconomy.pdf (accessed on 07/01/2020)

50. Prieto, I., and Santana, P. (2012). Building ambidexterity: The role of human resource practices in the performance of firms from Spain. Human Resource Management, (51), pp.189-212.

51. Rerup, C., and Feldman, M. S. (2011). Routines as a source of change in organizational schemata: The role of trial-and-error learning. Academy of Management Journal, (54:3), pp.577-610.

52. Rosenkopf, L., and Nerkar, A. (2001). Beyond local search: boundary-spanning, exploration, and impact in the optical disk industry. Strategic Management Journal, 22(4), pp.287-306. 
53. Rosacker, K. M., and Rosacker, R. E. (2010). Information technology project management within public sector organizations. Journal of Enterprise Information Management, 23(5), pp.587-594.

54. Rothaermel, F. T., and Alexandre, M. T. (2009). Ambidexterity in technology sourcing: The moderating role of absorptive capacity. Organization Science, 20(4), pp.759-780.

55. Rowe, G., and Wright, G. (1999). The Delphi technique as a forecasting tool: issues and analysis. International Journal of Forecasting, 15(4), pp.353-375.

56. Sallehudin, H., Razak, R., and Ismail, M. (2015). Factors Influencing Cloud Computing Adoption in the Public Sector: An Empirical Analysis. Journal of Entrepreneurship and Business, 3(1), pp.30-45.

57. Schmidt, R. C. (1997). Managing Delphi surveys using nonparametric statistical techniques. Decision Sciences, 28(3), pp.763-774.

58. Schneider, S., and Sunyaev, A. (2016). Determinant factors of cloud-sourcing decisions: reflecting on the IT outsourcing literature in the era of cloud computing. Journal of Information Technology, 31(1), pp.1-31.

59. Simsek, Z., Heavey, C., Veiga, J. F., and Souder, D. (2009). A typology for aligning organizational ambidexterity's conceptualizations, antecedents, and outcomes. Journal of Management Studies, 46(5), pp.864894.

60. Sirkemaa, S. (2002). IT infrastructure management and standards. Proceedings of the International Conference on Information Technology: Coding and Computing (ITCC'02).

61. Steensma, H. K., and Corley, K. G. (2001). Organizational Context as a Moderator of Theories on Firm Boundaries for Technology Sourcing. Academy of Management Journal, 44(2), pp. 271-291.

62. Sydow, J., Schreyögg, G., and Koch, J. (2009). Organizational path dependence: Opening the black box. Academy of Management Review, 34(4), pp.689-709.

63. Tushman, M. L., and O'Reilly, C. A. (1996). Ambidextrous organizations: Managing evolutionary and revolutionary change. California Management Review, 38(4), pp.8-29.

64. Van de Ven, A. H., and Poole, M. S. (1995). Explaining development and change in organizations. Academy of Management Review, 20(3), pp.510-540.

65. Wyld, D. C. (2009). Moving to the cloud: An introduction to cloud computing in government. IBM Center for the Business of Government.

66. Zardini, A., Rossignoli, C., and Ricciardi, F. (2016). A bottom-up path for IT management success: From infrastructure quality to competitive excellence. Journal of Business Research, 69(5), pp.1747-1752. 


\section{Appendix \#1 - Complete list of the EXPLOITATION-Focused Practices Identified in the Delphi Study}

\begin{tabular}{|c|c|c|c|c|c|c|c|c|}
\hline \# & Labels & Descriptions & \multicolumn{2}{|c|}{$\begin{array}{l}\text { Nature of practices } \\
\text { Sourcing-related }\end{array}$} & \multicolumn{2}{|c|}{ Sourcing Approach } & \multicolumn{2}{|c|}{$\begin{array}{c}\text { Type of } \\
\text { Technology }\end{array}$} \\
\hline \multicolumn{3}{|c|}{ EXPLOITATION - Category \#1 KNOWLEDGE MANAGEMENT and COMPETENCIES } & Related & Not-rel. & Insourcing & Outsourcing & Known & New \\
\hline 1. & Knowledge of business needs & $\begin{array}{l}\text { Ensure that business units are able to evaluate, formulate } \\
\text { and communicate their needs and that IT employees } \\
\text { understand these business needs, that their knowledge is } \\
\text { up to date, so that technology infrastructure is aligned } \\
\text { with business needs. }\end{array}$ & & $\mathbf{X}$ & & & & \\
\hline 2. & $\begin{array}{l}\text { Foster collaboration between } \\
\text { development teams and business } \\
\text { units (Agile and DevOps) }\end{array}$ & $\begin{array}{l}\text { Deploying technology infrastructure development and } \\
\text { delivery approaches, such as Agile or DevOps, which } \\
\text { foster close collaboration between development teams and } \\
\text { business units. }\end{array}$ & & $\mathbf{X}$ & & & & \\
\hline 3. & $\begin{array}{l}\text { Involvement in communities of } \\
\text { practice }\end{array}$ & $\begin{array}{l}\text { Engage in communities of practice to share and collect } \\
\text { experience and knowledge of management of technology } \\
\text { infrastructure. }\end{array}$ & & $\mathbf{X}$ & & & & \\
\hline 4. & Maintain IT skills & $\begin{array}{l}\text { Support IT employees in updating their IT skills and } \\
\text { knowledge by providing in-house training and/or by } \\
\text { financing specialized external training, conferences, etc. } \\
\text { These competencies must be aligned with organizational } \\
\text { needs and the evolution of IT in the marketplace. }\end{array}$ & & $\mathbf{X}$ & & & & \\
\hline 5. & $\begin{array}{l}\text { Establish a continuous improvement } \\
\text { program }\end{array}$ & $\begin{array}{l}\text { Deploy a continuous improvement program of the } \\
\text { technological infrastructure that involves both IT } \\
\text { employees as well as internal and external users. }\end{array}$ & $\bar{X}$ & & $\mathbf{X}$ & & $\mathbf{X}$ & $\mathbf{X}$ \\
\hline 6. & $\begin{array}{l}\text { Establish a knowledge management } \\
\text { system }\end{array}$ & $\begin{array}{l}\text { The implementation of a knowledge management system } \\
\text { increases the efficiency and level of expertise of the } \\
\text { resources responsible for ensuring the sustainability of the } \\
\text { IT infrastructure. }\end{array}$ & & $\mathbf{X}$ & & & & \\
\hline 7. & Transfer and duplicate IT Skills & $\begin{array}{l}\text { Ensure constant and ongoing transfer of IT skills between } \\
\text { internal employees and, where possible, between external } \\
\text { resources (e.g. consultants) and internal employees. In the } \\
\text { case of critical IT skills, ensure a duplication of these IT } \\
\text { skills. }\end{array}$ & $\mathbf{X}$ & & $\mathbf{X}$ & $\mathbf{X}$ & $\mathbf{X}$ & $\mathbf{X}$ \\
\hline 8. & Develop technological watch & $\begin{array}{l}\text { Put in place practices and a culture that fosters the } \\
\text { monitoring of technological developments, to learn from } \\
\text { other organizations, to discover new tools or approaches, } \\
\text { etc. }\end{array}$ & & $\mathbf{X}$ & & & & \\
\hline \multicolumn{3}{|c|}{ EXPLOITATION - Category \#2- GOVERNANCE } & Related & Not-rel. & Insourcing & Outsourcing & Known & New \\
\hline 9. & Adopt a modular approach & $\begin{array}{l}\text { Adopt a modular approach by establishing a strong } \\
\text { technological infrastructure foundation that can be } \\
\text { developed with additional modules. }\end{array}$ & $\mathbf{X}$ & & $\mathbf{X}$ & $\mathbf{X}$ & $\mathbf{X}$ & $\mathbf{X}$ \\
\hline 10. & $\begin{array}{l}\text { Centralize IT and data center } \\
\text { management }\end{array}$ & $\begin{array}{l}\text { Centralize the management of IT and data centers to } \\
\text { reduce the size, overall cost, complexity and needs of } \\
\text { technological infrastructure. }\end{array}$ & & $\mathbf{X}$ & & & & \\
\hline 11. & Consolidate and standardize the & $\begin{array}{l}\text { Consolidate and standardize the development and support } \\
\text { practices, e.g., guidelines, architecture standards, }\end{array}$ & & $\mathbf{X}$ & & & & \\
\hline
\end{tabular}




\begin{tabular}{|c|c|c|c|c|c|c|c|c|}
\hline & development and support practices & $\begin{array}{l}\text { technologies, programming languages, approaches, } \\
\text { methods, tools, etc., to enable reuse, valorization and } \\
\text { optimization of the existing technological infrastructure. }\end{array}$ & & & & & & \\
\hline 12. & $\begin{array}{l}\text { Establish a technological } \\
\text { infrastructure governance } \\
\text { framework }\end{array}$ & $\begin{array}{l}\text { Establish a technological infrastructure governance } \\
\text { framework, e.g., IT orientations, values, guidelines, } \\
\text { objectives, RACI matrix, decision-making processes, etc., } \\
\text { for all employees involved in the development, } \\
\text { maintenance, and evolution of the technological } \\
\text { infrastructure. }\end{array}$ & & $\overline{\mathbf{X}}$ & & & & \\
\hline 13. & $\begin{array}{l}\text { Establish a data governance } \\
\text { framework and IT utilization } \\
\text { guidelines }\end{array}$ & $\begin{array}{l}\text { Establish a data governance framework that encompasses } \\
\text { the processes, policies, practices, and structures needed to } \\
\text { orchestrate the people, processes, and use of technologies } \\
\text { within an organization and optimize the collection, } \\
\text { storage, use and dissemination of IT and data. }\end{array}$ & & $\overline{\mathbf{X}}$ & & & & \\
\hline 14. & $\begin{array}{l}\text { Establish a licensing and purchase of } \\
\text { hardware / software policy }\end{array}$ & $\begin{array}{l}\text { Setting objectives, guidelines, guidelines, a RACI matrix, } \\
\text { etc. to oversee the purchase and renewal of licenses, } \\
\text { hardware and software. }\end{array}$ & $\mathbf{X}$ & & $\mathbf{X}$ & $\mathbf{X}$ & $\mathbf{X}$ & $\mathbf{X}$ \\
\hline 15. & $\begin{array}{l}\text { Establish standards and performance } \\
\text { norms for the technological } \\
\text { infrastructure }\end{array}$ & $\begin{array}{l}\text { Define technical standards and performance norms in } \\
\text { terms of speed, volume, safety, risks, etc. to ensure that } \\
\text { the technological infrastructure's performance and } \\
\text { capacity planning are optimally managed. }\end{array}$ & & $\mathbf{X}$ & & & & \\
\hline 16. & $\begin{array}{l}\text { Establish and monitor the evolution } \\
\text { of the portfolio of the components of } \\
\text { the technological infrastructure }\end{array}$ & $\begin{array}{l}\text { Establish a portfolio of technology infrastructure } \\
\text { components and track their evolution including internal } \\
\text { developments, external vendors, as well as hardware, } \\
\text { software. }\end{array}$ & $\mathbf{X}$ & & $\mathbf{X}$ & $\mathbf{X}$ & $\mathbf{X}$ & \\
\hline 17. & $\begin{array}{l}\text { Assess and monitor the capabilities of } \\
\text { the technological infrastructure } \\
\text { components }\end{array}$ & $\begin{array}{l}\text { Establishment of a governance structure, e.g. processes } \\
\text { and committees, to evaluate, monitor, and control of the } \\
\text { capacity of the technological infrastructure components. }\end{array}$ & & $\bar{X}$ & & & & \\
\hline 18. & $\begin{array}{l}\text { Promote the use of standardized } \\
\text { technologies }\end{array}$ & $\begin{array}{l}\text { Promote the use of standardized technologies (avoid over- } \\
\text { tailoring) that are compatible and mastered by the } \\
\text { organization and whose reliability and performance have } \\
\text { been demonstrated. }\end{array}$ & & $\mathbf{X}$ & & & & \\
\hline \multicolumn{3}{|c|}{ EXPLOITATION - Category \#3 - PARTNERSHIP } & Related & Not-rel. & Insourcing & Outsourcing & Known & New \\
\hline 19. & $\begin{array}{l}\text { Establish inter-organizational } \\
\text { partnerships }\end{array}$ & $\begin{array}{l}\text { Engage in partnerships with external organizations facing } \\
\text { similar technological infrastructure challenges / issues in } \\
\text { order to share resources, expertise, knowledge, costs, and } \\
\text { risks related to the development and delivery of } \\
\text { technology solutions }\end{array}$ & $\mathbf{X}$ & & & $\mathbf{X}$ & $\mathbf{X}$ & $\mathbf{X}$ \\
\hline 20. & Renegotiate contracts for extensions & $\begin{array}{l}\text { Renegotiate with external service providers to extend } \\
\text { SLA (service level agreement) beyond the scheduled end } \\
\text { date. }\end{array}$ & $\mathbf{X}$ & & & $\mathbf{X}$ & $\mathbf{X}$ & $\mathbf{X}$ \\
\hline 21. & $\begin{array}{l}\text { Do business with local service } \\
\text { providers }\end{array}$ & $\begin{array}{l}\text { Sign service agreements with local providers because } \\
\text { proximity can facilitate communication and collaboration. }\end{array}$ & $\mathbf{X}$ & & & $\mathbf{X}$ & $\mathbf{X}$ & $\mathbf{X}$ \\
\hline 22. & $\begin{array}{l}\text { Use of external consultants } \\
\text { specialized in the management of the } \\
\text { technological infrastructure }\end{array}$ & $\begin{array}{l}\text { Use external consulting services specializing in the } \\
\text { management of technology infrastructure, e.g. } \\
\text { development, maintenance and evolution. }\end{array}$ & $\mathbf{X}$ & & & $\mathbf{X}$ & $\mathbf{X}$ & $\mathbf{X}$ \\
\hline
\end{tabular}




\begin{tabular}{|c|c|c|c|c|c|c|c|c|}
\hline 23. & $\begin{array}{l}\text { Use of external services (e.g. } \\
\text { outsourcing) }\end{array}$ & $\begin{array}{l}\text { Use external services by transferring the support, } \\
\text { maintenance, evolution and/or development of some or all } \\
\text { the technological infrastructure components to a service } \\
\text { provider with performance obligations stipulated in a } \\
\text { SLA. }\end{array}$ & $\mathbf{X}$ & & & $\mathbf{X}$ & $\mathbf{X}$ & $\mathbf{X}$ \\
\hline 24. & $\begin{array}{l}\text { Establish a contract management } \\
\text { structure and policy }\end{array}$ & $\begin{array}{l}\text { Establishment of a specialized team and a policy (e.g. } \\
\text { orientation, guidelines, objectives, strategy) for bid } \\
\text { management and contract management, e.g., negotiation, } \\
\text { drafting, follow-up, etc. }\end{array}$ & $\overline{\mathbf{X}}$ & & $\overline{\mathbf{X}}$ & $\overline{\mathbf{X}}$ & $\mathbf{X}$ & $\mathbf{X}$ \\
\hline \multicolumn{3}{|c|}{ EXPLOITATION - Category \#4 - STRATEGY } & Related & Not-rel. & Insourcing & Outsourcing & Known & New \\
\hline 25. & $\begin{array}{l}\text { Develop an organizational policy on } \\
\text { "Bring your own devices" (BYOD) }\end{array}$ & $\begin{array}{l}\text { Develop a policy and provide an environment, e.g. } \\
\text { networking, applications, support, security, web services, } \\
\text { etc., to support the "Bring your own device" approach. }\end{array}$ & $\mathbf{X}$ & & $\mathbf{X}$ & & $\mathbf{X}$ & $\mathbf{X}$ \\
\hline 26. & $\begin{array}{l}\text { Develop a strategic vision of } \\
\text { technological infrastructure }\end{array}$ & $\begin{array}{l}\text { Develop a vision of the technological infrastructure and } \\
\text { the IT function, with all stakeholders of the organization } \\
\text { to meet current needs, anticipate future needs and } \\
\text { prioritize investments. It is important to establish an IT } \\
\text { strategic plan, e.g., objectives, roles, impacts, risks, etc., } \\
\text { aligned with the organization's strategic objectives to } \\
\text { prioritize IT investments and the delivery of technological } \\
\text { infrastructure components. }\end{array}$ & $\mathbf{X}$ & & $\mathbf{X}$ & $\mathbf{X}$ & $\mathbf{X}$ & $\mathbf{X}$ \\
\hline 27. & $\begin{array}{l}\text { Develop and document the business } \\
\text { architecture plan (including } \\
\text { technology infrastructure) }\end{array}$ & $\begin{array}{l}\text { Develop and document a business architecture plan, } \\
\text { including the technological infrastructure components, to } \\
\text { meet future needs and to ensure that new and / or } \\
\text { outsourced components are consistent and fit into the } \\
\text { business architecture plan. }\end{array}$ & $\mathbf{X}$ & & $\overline{\mathbf{X}}$ & $\bar{X}$ & $\mathbf{X}$ & $\mathbf{X}$ \\
\hline 28. & $\begin{array}{l}\text { Develop and monitor maintenance } \\
\text { and replacement plans }\end{array}$ & $\begin{array}{l}\text { Establish and monitor the maintenance and replacement } \\
\text { plan for the technological infrastructure components in } \\
\text { order to anticipate changes, budget these changes, spread } \\
\text { the replacement of certain components, avoid breakage or } \\
\text { obsolescence, minimize impacts on users, etc. }\end{array}$ & $\bar{X}$ & & $\mathbf{X}$ & $\mathbf{X}$ & $\mathbf{X}$ & $\mathbf{X}$ \\
\hline 29. & Use reliable software & $\begin{array}{l}\text { Ensure that the software developed (or configured) is as } \\
\text { reliable as possible as soon as it goes into production, } \\
\text { making sure that it has been rigorously tested and passed } \\
\text { through a business approval cycle }\end{array}$ & & $\mathbf{X}$ & & & & \\
\hline 30. & Establishing an IT Strategic Plan & $\begin{array}{l}\text { Establish an IT strategic plan, e.g., objectives, roles, } \\
\text { impacts, risks, etc., aligned with the organization's } \\
\text { strategic objectives to prioritize IT investments and the } \\
\text { delivery of technological infrastructure components }\end{array}$ & $\overline{\mathbf{X}}$ & & $\mathbf{X}$ & $\overline{\mathbf{X}}$ & $\bar{X}$ & $\overline{\mathbf{X}}$ \\
\hline 31. & Establish a service offer & $\begin{array}{l}\text { Establish and IT services offer that meets the needs of the } \\
\text { organization's stakeholders in order to make the } \\
\text { technological infrastructure in place profitable and help } \\
\text { the organization to operate, evolve, and transform itself. }\end{array}$ & $\mathbf{X}$ & & $\overline{\mathbf{X}}$ & $\mathbf{X}$ & $\bar{X}$ & \\
\hline 32. & $\begin{array}{l}\text { Evaluate the added value of the } \\
\text { components of the tech. infra. }\end{array}$ & $\begin{array}{l}\text { Evaluate and demonstrate the added value of the different } \\
\text { components of the technological infrastructure for the } \\
\text { organization and its stakeholders }\end{array}$ & & $\mathbf{X}$ & & & & \\
\hline 33. & $\begin{array}{l}\text { Acquire reliable technological } \\
\text { equipment }\end{array}$ & $\begin{array}{l}\text { Acquire "quality" technological hardware and equipment } \\
\text { that can be more expensive to purchase in the short term, } \\
\text { but more reliable and durable in the long term. }\end{array}$ & $\mathbf{X}$ & & & $\mathbf{X}$ & & $\bar{X}$ \\
\hline
\end{tabular}




\begin{tabular}{|c|c|c|c|c|c|c|c|c|}
\hline 34. & Set up shared services & $\begin{array}{l}\text { Set up shared services to share costs, centralize tenders, } \\
\text { consolidate acquisitions and standardize technology } \\
\text { infrastructure. }\end{array}$ & $\bar{X}$ & & $\bar{X}$ & & $\bar{X}$ & $\mathbf{X}$ \\
\hline 35. & $\begin{array}{l}\text { Optimize and reuse technological } \\
\text { components }\end{array}$ & $\begin{array}{l}\text { Optimize and reuse technology components from some } \\
\text { business units in other units with smaller needs or in } \\
\text { development environments (R\&D). }\end{array}$ & & $\mathbf{X}$ & & & & \\
\hline \multicolumn{3}{|c|}{ EXPLOITATION - Category \#5 - TECHNOLOGY } & Related & Not-rel. & Insourcing & Outsourcing & Known & New \\
\hline 36. & $\begin{array}{l}\text { Analyze the operating data of the } \\
\text { tech. infra. using artificial and } \\
\text { business intelligence tools }\end{array}$ & $\begin{array}{l}\text { Use business intelligence tools such as machine learning, } \\
\text { data analysis, etc. to better understand, for example, } \\
\text { energy consumption curves, break patterns, etc. and } \\
\text { support the maintenance and evolution of the tech. infra. }\end{array}$ & & $\bar{X}$ & & & & \\
\hline 37. & $\begin{array}{l}\text { Implement a Service Oriented } \\
\text { Architecture }\end{array}$ & $\begin{array}{l}\text { Use web services, e.g., software (SaaS), infrastructure } \\
\text { (IaaS) and/or platform (PaaS), through public, private and } \\
\text { / or hybrid clouds. }\end{array}$ & $\bar{X}$ & & $\bar{X}$ & $\mathbf{X}$ & & $\mathbf{X}$ \\
\hline 38. & $\begin{array}{l}\text { Automate and digitize monitoring } \\
\text { and maintenance tasks }\end{array}$ & $\begin{array}{l}\text { Automate and digitize certain technology infrastructure } \\
\text { monitoring and maintenance activities, such as automatic } \\
\text { computer shutdown or automatic updates, to reduce } \\
\text { manual tasks, improve identification and problem solving, } \\
\text { optimizing the use of resources, etc. }\end{array}$ & & $\mathbf{X}$ & & & & \\
\hline 39. & Create and publish API & $\begin{array}{l}\text { Create and publish APIs (application programming } \\
\text { interface) to facilitate the exchange of information } \\
\text { between different software }\end{array}$ & & $\mathbf{X}$ & & & & \\
\hline 40. & $\begin{array}{l}\text { Establish a policy for energy } \\
\text { efficiency of the technological } \\
\text { infrastructure }\end{array}$ & $\begin{array}{l}\text { Establish a policy, e.g., goals, guidelines, directions, } \\
\text { levels, etc., to ensure that new technology devices } \\
\text { deployed during upgrades or replacements meet pre- } \\
\text { established energy efficiency criteria and minimize } \\
\text { environmental impacts. }\end{array}$ & & $\mathbf{X}$ & & & & \\
\hline 41. & Use of Open Source & $\begin{array}{l}\text { Use open source software to operate and evolve the } \\
\text { technology infrastructure and to gain the benefits of } \\
\text { flexibility (avoid the "lock-in" of proprietary software } \\
\text { vendors) on the evolution or potential removal of software }\end{array}$ & & $\mathbf{X}$ & & & & \\
\hline 42. & $\begin{array}{l}\text { Ensure redundancy of critical } \\
\text { components }\end{array}$ & $\begin{array}{l}\text { Ensure redundancy of the technology infrastructure's } \\
\text { critical components, e.g. server, data, expertise, etc. in } \\
\text { order to protect key organizational operations and data. }\end{array}$ & $\mathbf{X}$ & & & $\mathbf{X}$ & $\mathbf{X}$ & \\
\hline 43. & Virtualize infrastructure & $\begin{array}{l}\text { Virtualize all components of the technological } \\
\text { infrastructure and network to separate the hardware and } \\
\text { software layers to extend the life of physical equipment } \\
\text { and simplify the physical infrastructure. }\end{array}$ & $\mathbf{X}$ & & $\mathbf{X}$ & $\mathbf{X}$ & & $\mathbf{X}$ \\
\hline 44. & Virtualize servers & $\begin{array}{l}\text { Virtualizing some applications and workstations (VDI - } \\
\text { Virtual Desktop Infrastructure) on servers will } \\
\text { significantly reduce the cost of power, heating / cooling, } \\
\text { human resources, nr. of workstations, data center, etc. }\end{array}$ & $\mathbf{X}$ & & $\mathbf{X}$ & $\mathbf{X}$ & & $\mathbf{X}$ \\
\hline 45. & Virtualize storage & $\begin{array}{l}\text { Virtualizing storage technologies will provide longer } \\
\text { amortization for older and less efficient storage } \\
\text { technologies. }\end{array}$ & $\mathbf{X}$ & & $\mathbf{X}$ & $\mathbf{X}$ & & $\mathbf{X}$ \\
\hline
\end{tabular}


Appendix \#2 - Complete list of the EXPLORATION-Focused Practices Identified in the Delphi Study

\begin{tabular}{|c|c|c|c|c|c|c|c|c|}
\hline \#. & Labels & Descriptions & \multicolumn{2}{|c|}{$\begin{array}{l}\text { Nature of practices } \\
\text { Sourcing-related }\end{array}$} & \multicolumn{2}{|c|}{ Sourcing Approach } & \multicolumn{2}{|c|}{$\begin{array}{c}\text { Type of } \\
\text { Technology }\end{array}$} \\
\hline \multicolumn{3}{|c|}{ EXPLORATION - Category \#1 - EMPLOYEES } & Related & Not-rel. & Insourcing & Outsourcing & Known & New \\
\hline 1. & Development of transversal skills & $\begin{array}{l}\text { Develop IT employee cross-functional skills in relation with } \\
\text { the organization's strategy. At the technological level, it } \\
\text { involves hiring or training employees on different } \\
\text { technology platforms and programming languages to bridge } \\
\text { old with new technological infrastructures, identify areas for } \\
\text { improvement, facilitate integration of technological } \\
\text { changes, etc. There is also a need to develop a good } \\
\text { understanding of the issues related to organization's strategy } \\
\text { such as the evolution of the IT infrastructure. }\end{array}$ & & $\mathbf{X}$ & & & & \\
\hline 2. & Implication of IT experts & $\begin{array}{l}\text { Involve internal technology expertise in the identification of } \\
\text { and decisional process related to the evolution of } \\
\text { technological infrastructures in order to better position the } \\
\text { organization, to identify solutions in line with the existing } \\
\text { IT, to prepare employees for the change (minimize } \\
\text { resistance), etc. }\end{array}$ & & $\mathbf{X}$ & & & & \\
\hline 3. & $\begin{array}{l}\text { Establishment of working } \\
\text { conditions favoring the retention of } \\
\text { employees }\end{array}$ & $\begin{array}{l}\text { Create working conditions that encourage retention, } \\
\text { collaboration and knowledge sharing between employees in } \\
\text { order to cope with technological developments, such as } \\
\text { appointing a "Chief happiness officer", promote the } \\
\text { reconciliation work-private life, etc. It is also important to } \\
\text { assess and manage the risks related to employee frustration } \\
\text { that that stem from factors such as changing assignments, } \\
\text { perceived cumbersome bureaucracy, etc. }\end{array}$ & & $\mathbf{X}$ & & & & \\
\hline 4. & $\begin{array}{l}\text { Plan for continuous development } \\
\text { skills }\end{array}$ & $\begin{array}{l}\text { Plan the development of employees' IT skills on an ongoing } \\
\text { basis by offering coaching, involving them in internal } \\
\text { training, sending them to seminars, etc. to ensure up-to-date } \\
\text { skills, cope with the emergency of new technologies and } \\
\text { enable technological change readiness. }\end{array}$ & & $\mathbf{X}$ & & & & \\
\hline 5. & $\begin{array}{l}\text { Implement an innovation policy } \\
\text { and internal contests }\end{array}$ & $\begin{array}{l}\text { Developing incentive mechanisms that encourage internal } \\
\text { innovation e.g., innovation contests on a regular basis to } \\
\text { stimulate thinking, sharing ideas, testing new technologies } \\
\text { and finding solutions to overcome organizational challenges } \\
\text { associated with technological evolution. }\end{array}$ & & $\mathbf{X}$ & & & & \\
\hline 6. & Nurture an open mindset culture & $\begin{array}{l}\text { Promote an organizational culture of open mindset with } \\
\text { regard to the management of technology infrastructure and } \\
\text { IT in general in the organization. }\end{array}$ & & $\bar{X}$ & & & & \\
\hline 7. & $\begin{array}{l}\text { Use of internship and hire young } \\
\text { graduates }\end{array}$ & $\begin{array}{l}\text { Use interns to introduce new ideas, new knowledge, new } \\
\text { work practices, new technologies, etc. }\end{array}$ & & $\mathbf{X}$ & & & & \\
\hline 8. & $\begin{array}{l}\text { Using crowd creativity } \\
\text { (Crowdsourcing) }\end{array}$ & $\begin{array}{l}\text { Use the creativity of external resources to learn about new } \\
\text { trends, concepts, and opportunities related to technological } \\
\text { developments. }\end{array}$ & & $\mathbf{X}$ & & & & \\
\hline
\end{tabular}




\begin{tabular}{|c|c|c|c|c|c|c|c|c|}
\hline \multicolumn{3}{|c|}{ EXPLORATION - Category \#2 - TECHNOLOGY } & Related & Not-rel. & Insourcing & Outsourcing & Known & New \\
\hline 9. & $\begin{array}{l}\text { Adopting reliable and evolutive } \\
\text { technologies }\end{array}$ & $\begin{array}{l}\text { Adopt components in the technology infrastructure that are } \\
\text { "flexible" and scalable, for example, components that can be } \\
\text { updated, enhanced and / or extended; promote open } \\
\text { standards and cloud computing; continuously test and adopt } \\
\text { new components, etc. }\end{array}$ & $\mathbf{X}$ & & & $\mathbf{X}$ & & $\mathbf{X}$ \\
\hline 10. & $\begin{array}{l}\text { Automate technological services in } \\
\text { a standardized way }\end{array}$ & $\begin{array}{l}\text { Automate technological services using market standards } \\
\text { (e.g., SDDC, Software-defined data center) to separate } \\
\text { organizational processes from technological infrastructures } \\
\text { and thus promote the evolution of infrastructure by } \\
\text { minimizing the impacts on the organizational processes. }\end{array}$ & & $\mathbf{X}$ & & & & \\
\hline 11. & Create spaces of creativity & $\begin{array}{l}\text { Create spaces for employees to be creative, for example, } \\
\text { "sandboxes" to develop and test prototypes, to "play" with } \\
\text { new technologies, to explore, and so on. }\end{array}$ & & $\mathbf{X}$ & & & & \\
\hline 12. & Migrate to cloud computing & $\begin{array}{l}\text { Migrate "on premise" systems to cloud computing platforms } \\
\text { in order to have greater flexibility, to respond to } \\
\text { unanticipated high demands, to ease the scalability of } \\
\text { systems, avoid in-house the management of systems } \\
\text { development. }\end{array}$ & $\mathbf{X}$ & & $\mathbf{X}$ & $\mathbf{X}$ & & $\mathbf{X}$ \\
\hline 13. & Openness and transparency & $\begin{array}{l}\text { Promote the use of open standards, open API and open data } \\
\text { to capitalize on IT communities to achieve systems } \\
\text { interoperability and better cope with technological } \\
\text { evolution. }\end{array}$ & & $\mathbf{X}$ & & & & \\
\hline 14. & Use of standards & $\begin{array}{l}\text { Promote the use of standards when acquiring, developing } \\
\text { and maintaining technological infrastructures in order to } \\
\text { standardize practices, facilitate the interoperability of } \\
\text { systems and ease the integration of emerging technologies }\end{array}$ & & $\mathbf{X}$ & & & & \\
\hline 15. & $\begin{array}{l}\text { Use of business and artificial } \\
\text { intelligence }\end{array}$ & $\begin{array}{l}\text { Use artificial intelligence tools, such as machine learning, to } \\
\text { exploit the data generated by technological infrastructure } \\
\text { (e.g. energy consumption, speed, number of errors, etc.) and } \\
\text { thus be better prepared to cope with technological change. }\end{array}$ & $\mathbf{X}$ & & $\mathbf{X}$ & $\mathbf{X}$ & & $\mathbf{X}$ \\
\hline 16. & Reuse of IT assets & $\begin{array}{l}\text { Reuse and adapt, where possible, existing technological } \\
\text { infrastructure components when implementing technological } \\
\text { innovations to optimize the use of existing technological } \\
\text { resources. }\end{array}$ & $\mathbf{X}$ & & $\mathbf{X}$ & & $\mathbf{X}$ & \\
\hline 17. & $\begin{array}{l}\text { Use of performance indicators to } \\
\text { evaluate infrastructure } \\
\text { performance }\end{array}$ & $\begin{array}{l}\text { Develop and use indicators to assess the performance of the } \\
\text { components of the technology infrastructure, e.g., costs, } \\
\text { volume, downtime, maintenance, etc. and thus identify the } \\
\text { components to be replaced. }\end{array}$ & & $\mathbf{X}$ & & & & \\
\hline \multicolumn{3}{|c|}{ EXPLORATION - Category \#3 - ARCHITECTURE } & Related & Not-rel. & Insourcing & Outsourcing & Known & New \\
\hline 18. & $\begin{array}{l}\text { Adopt an architecture in micro- } \\
\text { services and modules }\end{array}$ & $\begin{array}{l}\text { Adopt a technological architecture of micro-services and } \\
\text { modules in order to promote a flow between applications } \\
\text { and hardware, to reuse micro-services, to facilitate the } \\
\text { extension, the elasticity and the evolution of the } \\
\text { technological infrastructure. }\end{array}$ & $\mathbf{X}$ & & $\mathbf{X}$ & $\mathbf{X}$ & & $\mathbf{X}$ \\
\hline 19. & $\begin{array}{l}\text { Adopt a service-oriented } \\
\text { architecture (SOA) }\end{array}$ & $\begin{array}{l}\text { Adopt a service-oriented architecture to enable a more } \\
\text { flexible and easier way to evolve technology infrastructure. }\end{array}$ & $\bar{X}$ & & $\bar{X}$ & $\overline{\mathbf{X}}$ & & $\mathbf{X}$ \\
\hline 20. & Define a corporate architecture & Define an enterprise architecture framework and evaluate all & $\mathbf{X}$ & & $\mathbf{X}$ & $\mathbf{X}$ & & $\mathbf{X}$ \\
\hline
\end{tabular}




\begin{tabular}{|c|c|c|c|c|c|c|c|c|}
\hline & framework & $\begin{array}{l}\text { elements of this architecture, e.g. processes, data, } \\
\text { technologies, applications, services, standards, structures, } \\
\text { etc. to meet organization's business objectives, guide } \\
\text { transformation, and sustainably manage technological } \\
\text { changes and infrastructure. }\end{array}$ & & & & & & \\
\hline 21. & $\begin{array}{l}\text { Define life cycle and design a } \\
\text { roadmap }\end{array}$ & $\begin{array}{l}\text { Define the life cycle of the components of the technological } \\
\text { infrastructure and design a road map of future components } \\
\text { replacement to anticipate technological developments and } \\
\text { investments, optimize technological changes, adapt these } \\
\text { technological evolutions to the organizational environment } \\
\text { and avoid obsolescence. }\end{array}$ & $\mathbf{X}$ & & $\bar{X}$ & $\mathbf{X}$ & & $\mathbf{X}$ \\
\hline 22. & Establish architectural teams & $\begin{array}{l}\text { Creation of a "business architecture" team responsible for } \\
\text { establishing the enterprise architecture framework, (e.g. } \\
\text { determining standards and guidelines) and an "operating } \\
\text { architecture" team responsible for determining - based on } \\
\text { the AE -, the products / services / methods to put in place a } \\
\text { roadmap based on the various major areas of the } \\
\text { technological infrastructure. }\end{array}$ & & $\mathbf{X}$ & & & & \\
\hline 23. & $\begin{array}{l}\text { Create a committee for IT } \\
\text { monitoring and prioritization }\end{array}$ & $\begin{array}{l}\text { Creating a committee to identify and monitor technology } \\
\text { needs, technological change and technology advancement to } \\
\text { align with the organization's enterprise architecture } \\
\text { framework and to raise organization's awareness of } \\
\text { technological infrastructure's roles. }\end{array}$ & & $\mathbf{X}$ & & & & \\
\hline \multicolumn{3}{|c|}{ EXPLORATION - Category \#4 - STRATEGY } & Related & Not-rel. & Insourcing & Outsourcing & Known & New \\
\hline 24. & $\begin{array}{l}\text { Adopt a "bring your own devices" } \\
\text { approach (BYOD) }\end{array}$ & $\begin{array}{l}\text { Adopt a "bring your own devices" approach, while setting } \\
\text { rules of supervision, to transfer to employees the } \\
\text { responsibility of anticipating, planning and managing the } \\
\text { evolution of technologies according to their needs. }\end{array}$ & $\bar{X}$ & & $\overline{\mathbf{X}}$ & & $\bar{X}$ & $\bar{X}$ \\
\hline 25. & $\begin{array}{l}\text { Adopt a portfolio management } \\
\text { approach }\end{array}$ & $\begin{array}{l}\text { Adopt a portfolio management of all technology projects to } \\
\text { be able to identify complementarity and balance between } \\
\text { technology infrastructure projects and digital transformation } \\
\text { projects. }\end{array}$ & $\mathbf{X}$ & & $\bar{X}$ & $\mathbf{X}$ & $\mathbf{X}$ & $\bar{X}$ \\
\hline 26. & Adopt Agile methodologies & $\begin{array}{l}\text { Adopt agile and iterative development methods, e.g. Scrum, } \\
\text { Devops, etc., to have the ability to improve continuously, to } \\
\text { deliver more frequently and quickly (to improve time-to- } \\
\text { market ratio), to adapt quickly to changes, to involve } \\
\text { business units, to have a better understanding of business } \\
\text { needs and to constantly readjust to technological } \\
\text { developments. }\end{array}$ & & $\mathbf{x}$ & & & & \\
\hline 27. & Development of business cases & $\begin{array}{l}\text { Develop business cases to demonstrate importance and } \\
\text { relevance (e.g. cost savings, productivity improvement, etc.) } \\
\text { to invest in new infrastructures technologies as well as the } \\
\text { risks and impacts on the organization of not investing in } \\
\text { these technologies }\end{array}$ & $\mathbf{X}$ & & $\mathbf{X}$ & $\bar{X}$ & $\mathbf{X}$ & $\mathbf{X}$ \\
\hline 28. & Expand the IT service offering & $\begin{array}{l}\text { Expand the IT service offerings and the technology } \\
\text { infrastructure required to provide these services by merging } \\
\text { or acquiring the technology services of external } \\
\text { organizations }\end{array}$ & $\mathbf{X}$ & & & $\mathbf{X}$ & $\mathbf{X}$ & $\mathbf{X}$ \\
\hline
\end{tabular}




\begin{tabular}{|c|c|c|c|c|c|c|c|c|}
\hline 29. & $\begin{array}{l}\text { Assess internal and external } \\
\text { technological risks }\end{array}$ & $\begin{array}{l}\text { Evaluate the probability of technology risks (internal and } \\
\text { external) and their potential impacts, to identify } \\
\text { Infrastructure components to be updated, extended or } \\
\text { replaced, to mitigate those risks. }\end{array}$ & $\mathbf{X}$ & & $\overline{\mathbf{X}}$ & $\overline{\mathbf{X}}$ & $\bar{X}$ & $\mathbf{X}$ \\
\hline 30. & $\begin{array}{l}\text { Implement mechanisms for } \\
\text { continuous improvement }\end{array}$ & $\begin{array}{l}\text { Establish mechanisms for continuous improvement of the } \\
\text { technological infrastructure in order to improve, simplify, } \\
\text { and anticipate technological developments, e.g., conducting } \\
\text { recurrent technological infrastructure evaluation by having } \\
\text { an interdisciplinary monitoring committee. }\end{array}$ & $\mathbf{X}$ & & $\bar{X}$ & & $\overline{\mathbf{X}}$ & \\
\hline 31. & Outsource & $\begin{array}{l}\text { Engaging in outsourcing practices to take advantage of } \\
\text { suppliers' expertise, innovation, and IT infrastructure. }\end{array}$ & $\bar{X}$ & & & $\bar{X}$ & $\bar{X}$ & $\bar{X}$ \\
\hline \multicolumn{3}{|c|}{ EXPLORATION - Category \#5 - COLLABORATION } & Related & Not-rel. & Insourcing & Outsourcing & Known & New \\
\hline 32. & $\begin{array}{l}\text { Collaborate with specialized firms } \\
\text { and research center }\end{array}$ & $\begin{array}{l}\text { Developing collaborations with research centers (university } \\
\text { centers or research groups) as well as technology firms, e.g. } \\
\text { Forrester, Gartner, etc. to share knowledge / experience and } \\
\text { maintain an up-to-date look at technology trends and } \\
\text { developments. }\end{array}$ & $\mathbf{X}$ & & & $\mathbf{X}$ & & $\mathbf{X}$ \\
\hline 33. & $\begin{array}{l}\text { Develop collaboration between } \\
\text { development and operation teams }\end{array}$ & $\begin{array}{l}\text { Facilitate the collaboration between the technological and } \\
\text { application infrastructure development teams and the } \\
\text { operation / maintenance teams in order to facilitate } \\
\text { knowledge sharing, and the identification of trends, needs, } \\
\text { ideas, etc. in connection with the evolution of technological } \\
\text { infrastructure. }\end{array}$ & $\mathbf{X}$ & & $\bar{X}$ & & & $\mathbf{X}$ \\
\hline 34. & $\begin{array}{l}\text { Develop collaboration between IT } \\
\text { and external partners }\end{array}$ & $\begin{array}{l}\text { Collaborate regularly with external partners, e.g. clients and } \\
\text { suppliers, to identify their needs, their expectations, their } \\
\text { vision (including the technological aspect); co-develop } \\
\text { technological solutions; implement a common technology } \\
\text { watch, etc. }\end{array}$ & $\mathbf{X}$ & & & $\mathbf{X}$ & & $\mathbf{X}$ \\
\hline 35. & $\begin{array}{l}\text { Develop collaboration between IT } \\
\text { and business units }\end{array}$ & $\begin{array}{l}\text { Collaborate regularly with users, business units and internal } \\
\text { decision-makers to identify their needs, develop a common } \\
\text { strategy, maintain appropriate alignment of evolution } \\
\text { efforts, develop and test new functions, share knowledge. } \\
\end{array}$ & $\mathbf{X}$ & & $\bar{X}$ & & & $\mathbf{X}$ \\
\hline 36. & Develop partnership & $\begin{array}{l}\text { Develop partnership with other organizations to co-develop } \\
\text { technology solutions, share employees, etc. (e.g., pool IT } \\
\text { services, share technology infrastructures). }\end{array}$ & $\mathbf{X}$ & & & $\mathbf{X}$ & & $\mathbf{X}$ \\
\hline 37. & $\begin{array}{l}\text { Involvement in communities of } \\
\text { practice }\end{array}$ & $\begin{array}{l}\text { Engage in communities of practices to share knowledge, } \\
\text { lessons learned, ideas, issues, challenges, practices, trends, } \\
\text { etc. related to the evolution of technological infrastructures. }\end{array}$ & $\mathbf{X}$ & & & $\bar{X}$ & & $\mathbf{X}$ \\
\hline \multicolumn{3}{|c|}{ EXPLORATION - Category \#6 - MONITORING } & Related & Not-rel. & Insourcing & Outsourcing & Known & New \\
\hline 38. & $\begin{array}{l}\text { Consult reports and professional } \\
\text { studies }\end{array}$ & $\begin{array}{l}\text { Continuously consult studies and reports published by } \\
\text { technology firms, for example, Gartner, McKinsey, etc., to } \\
\text { track technological developments, predict trends, and } \\
\text { identify approaches / strategies to prepare for them. }\end{array}$ & & $\overline{\mathbf{X}}$ & & & & \\
\hline 39. & $\begin{array}{l}\text { Create an organizational culture } \\
\text { and implement a structure to foster } \\
\text { technology watch }\end{array}$ & $\begin{array}{l}\text { Establish a technology watch culture and structure to } \\
\text { continually monitor technological developments; changing } \\
\text { practices, trends, ways of doing things, assessing their } \\
\text { relevance to the organization; to anticipate and prepare for } \\
\text { technological challenges, etc. }\end{array}$ & & $\bar{X}$ & & & & \\
\hline
\end{tabular}




\begin{tabular}{|c|l|l|l|l|l|l|}
\hline 40. & Establish a center of excellence & $\begin{array}{l}\text { Set up a center of excellence to share knowledge, projects, } \\
\text { expertise, anticipate changes and prepare for challenges } \\
\text { related to the evolution of technological infrastructure }\end{array}$ & & $\mathbf{X}$ & & \\
\hline 41. & $\begin{array}{l}\text { Participation to practitioner } \\
\text { conferences }\end{array}$ & $\begin{array}{l}\text { Encourage employees' participation to practitioner } \\
\text { conferences to have access to new trends and ideas, share } \\
\text { experiences and best practices, etc. }\end{array}$ & & $\mathbf{X}$ & & \\
\hline 42. & Use of external experts & $\begin{array}{l}\text { Use external experts / consultants to gain access to new } \\
\text { knowledge, assist the organization in planning the evolution } \\
\text { of the technology infrastructure, have expert assistance to } \\
\text { make specific IT choices, facilitate digital transformations, } \\
\text { have an external evaluation of the internal work practices. }\end{array}$ & $\mathbf{X}$ & & $\mathbf{X}$ & \\
\hline
\end{tabular}




\section{Appendix \#3 - EXPLOITATION-Focused Sourcing Practices - Final Ranking}

\begin{tabular}{|c|c|c|c|c|}
\hline \multirow{2}{*}{$\#$} & \multirow{2}{*}{ EXPLOITATION-Focused Practices } & \multicolumn{3}{|c|}{ Ranking } \\
\hline & & Public & Private & Academic \\
\hline 33. & Acquire reliable technological equipment & 2 & & \\
\hline 44. & Virtualize servers & 3 & 7 & \\
\hline 42. & Ensure redundancy of critical components & 5 & & \\
\hline 43. & Virtualize infrastructure & 6 & 6 & \\
\hline 37. & Implement a Service Oriented Architecture & 7 & 5 & \\
\hline 28. & Develop and monitor maintenance and replacement plans & 10 & & \\
\hline 7. & Transfer and duplicate IT Skills & 13 & 11 & \\
\hline 26. & Develop a strategic vision of technological infrastructure & & 1 & 1 \\
\hline 45. & Virtualize storage & & 3 & 10 \\
\hline 27. & $\begin{array}{r}\text { Develop and document the business architecture plan (including technology } \\
\text { infrastructure) }\end{array}$ & 14 & 4 & \\
\hline 5. & Establish a continuous improvement program & 4 & 12 & 3 \\
\hline 9. & Adopt a modular approach & & & 6 \\
\hline 14. & Establish a licensing and purchase of hardware / software policy & & & \\
\hline 16. & $\begin{array}{r}\text { Establish and monitor the evolution of the portfolio of the components of the } \\
\text { technological infrastructure }\end{array}$ & & & \\
\hline 19. & Establish inter-organizational partnerships & & & \\
\hline 20. & Renegotiate contracts for extensions & & & \\
\hline 21. & Do business with local service providers & & & \\
\hline 22. & $\begin{array}{r}\begin{array}{r}\text { Use of external consultants specialized in the management of the technological } \\
\text { infrastructure }\end{array} \\
\end{array}$ & & & \\
\hline 23. & Use of external services (e.g. outsourcing) & & & \\
\hline 24. & Establish a contract management structure and policy & & & \\
\hline 25. & Develop an organizational policy on "Bring your own devices (BYOD)" & & & \\
\hline 30. & Establishing an IT Strategic Plan & & & \\
\hline 31. & Establish a service offer & & & \\
\hline 34. & Set up shared services & & & \\
\hline
\end{tabular}




\section{Appendix \#4 - EXPLORATION-Focused Sourcing Practices - Final Ranking}

\begin{tabular}{|c|c|c|c|c|}
\hline \multirow{2}{*}{ \# } & \multirow{2}{*}{ EXPLORATION-Focused Practices } & \multicolumn{3}{|c|}{ Ranking } \\
\hline & & Public & Private & Academic \\
\hline 9. & Adopting reliable and evolutive technologies & 1 & & \\
\hline 35. & Develop collaboration between IT and business units & 2 & 3 & 1 \\
\hline 30. & Implement mechanisms for continuous improvement & 4 & 9 & 5 \\
\hline 20. & Define a corporate architecture framework & 5 & & \\
\hline 29. & Assess internal and external technological risks & 10 & & \\
\hline 16. & Reuse of IT assets & 13 & & 9 \\
\hline 31. & Outsource & 14 & & 15 \\
\hline 21. & Define life cycle and design a roadmap & & 4 & \\
\hline 42. & Use of external experts & & 8 & \\
\hline 12. & Migrate to cloud computing & 3 & 10 & 11 \\
\hline 15. & Use of business and artificial intelligence & & 12 & 12 \\
\hline 33. & Develop collaboration between development and operation teams & & & 3 \\
\hline 34. & Develop collaboration between IT and external partners & & & 8 \\
\hline 18. & Adopt an architecture in micro-services and modules & & & \\
\hline 19. & Adopt a service-oriented architecture (SOA) & & & \\
\hline 24. & Adopt a "bring your own device" approach (BYOD) & & & \\
\hline 25. & Adopt a portfolio management approach & & & \\
\hline 36. & Develop partnership & & & \\
\hline 37. & Involvement in communities of practice & & & \\
\hline 27. & Development of business cases & & & \\
\hline 28. & Expand the IT service offering & & & \\
\hline 32. & Collaborate with specialized firms and research center & & & \\
\hline
\end{tabular}




\section{Appendix \#5 -Ambidextrous Sourcing Practices - Complete list}

\begin{tabular}{|c|c|c|c|c|}
\hline ID & EXPLOITATION - Focused Practices & A-Dex* & EXPLORATION - Focused Practices & ID \\
\hline 5 & Establish a continuous improvement program & $\leftrightarrow$ & Implement mechanisms for continuous improvement & 30 \\
\hline 7 & Transfer and duplicate IT Skills & & & \\
\hline 9 & Adopt a modular approach & $\leftarrow$ & Adopt an architecture in micro-services and modules & 18 \\
\hline 14 & Establish a licensing and purchase of hardware / software policy & & & \\
\hline 16 & $\begin{array}{r}\text { Establish and monitor the evolution of the portfolio of the components of } \\
\text { the ITI }\end{array}$ & $\leftarrow$ & Adopt a portfolio management approach & 25 \\
\hline 19 & Establish inter-organizational partnerships & $\leftarrow$ & Develop partnership & 36 \\
\hline 20 & Renegotiate contracts for extensions & & & \\
\hline 21 & Do business with local service providers & & & \\
\hline 22 & Use of external consultants specialized in the management of the ITI & 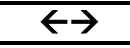 & Use of external experts & 42 \\
\hline 23 & Use of external services (e.g. outsourcing) & $\leftrightarrow$ & Outsource & 31 \\
\hline 24 & Establish a contract management structure and policy & & & \\
\hline 25 & Develop an organizational policy on "Bring your own devices (BYOD)" & $\leftarrow$ & Adopt a "bring your own devices" approach (BYOD) & 24 \\
\hline 26 & Develop a strategic vision of technological infrastructure & & & \\
\hline 27 & $\begin{array}{r}\text { Develop and document the business architecture plan (including } \\
\text { technology infrastructure) }\end{array}$ & $\leftrightarrow$ & Define a corporate architecture framework & 20 \\
\hline 28 & Develop and monitor maintenance and replacement plans & $\leftarrow$ & Define life cycle and design a roadmap & 21 \\
\hline 30 & Establishing an IT Strategic Plan & & & \\
\hline 31 & Establish a service offer & 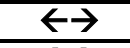 & Expand the IT service offering & 28 \\
\hline 33 & Acquire reliable technological equipment & $\leftarrow$ & Adopting reliable and evolutive technologies & 9 \\
\hline 34 & Set up shared services & & & \\
\hline 37 & Implement a Service Oriented Architecture & $\leftrightarrow$ & Adopt a service-oriented architecture (SOA) & 19 \\
\hline 42 & Ensure redundancy of critical components & & & \\
\hline 43 & Virtualize infrastructure & $\leftrightarrow$ & Migrate to cloud computing & 12 \\
\hline 44 & Virtualize servers & $\leftarrow$ & Migrate to cloud computing & 12 \\
\hline \multirow[t]{9}{*}{45} & Virtualize storage & $\leftarrow$ & Migrate to cloud computing & 12 \\
\hline & & & Use of business and artificial intelligence & 15 \\
\hline & & & Reuse of IT assets & 16 \\
\hline & & & Development of business cases & 27 \\
\hline & & & Assess internal and external technological risks & 29 \\
\hline & & & Collaborate with specialized firms and research center & 32 \\
\hline & & & Develop collaboration between development and operation teams & 33 \\
\hline & & & Develop collaboration between IT and business units & 35 \\
\hline & & & Involvement in communities of practice & 37 \\
\hline
\end{tabular}

*A-Dex = Ambidextrous relationship between exploitation-focused and exploration-focused sourcing practices 